\title{
KUALITAS FISIK ANTIMICROBIAL EDIBLE FILM (AmEF) DENGAN EKSTRAK DAUN TEH (Camellia sinensis) DARI GELATIN LIMBAH TULANG AYAM
}

\section{ANTIMICROBIAL EDIBLE FILM (AmEF) WITH TEA LEAF EXTRACT (Camellia sinensis) MADE FROM CHICKEN WASTE GELATIN PHYSICAL QUALITY}

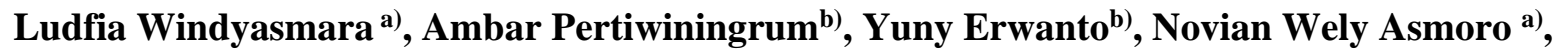 \\ Afriyantia) \\ a)Fakultas Pertanian, Universitas Veteran Bangun Nusantara, Sukoharjo \\ b)Fakultas Peternakan, Universitas Gadjah Mada, Yogyakarta
}

ABSTACT

Article history

Approved: June 1, 2018

* Corresponding author:

E-mail:

windyasmaraludfia@gm

ail.com
This study intends to find out the impact of green tea leaves' concentration and heating temperature on the physical quality of the antimicrobial edible film (AmEF) made from chicken bone gelatin. This study also utilizes chicken bone waste, in oder to increase both monetary value and the usefulness of that waste. The bone gelatin will then be utilized as AMeF and combined with green tea leaves' extract (Camellia sinensis) that used as sausage wrapper. Several stages have been taken placed as follow: chicken bone gelatin production; green tea leaves extraction; and tea leaves' extract-AMeF production. cCompletely randomized design with the factorial pattern was used in this study. Data was statistically analyzed using uni-variate analysis with 5\% significance rate. Duncan's Multiple Range Test (DMRT) will later be used to further test if there is a difference between each treatment. The physical qualities of AmEF that tested in this study include clarity, color, and thickness. The result of this study shows that a clarity value of AmEF was ranged between 0.62-2.12 abs, color was $0.87-2.60$ abs, and $0.015-0.023 \mathrm{~mm}$ of thickness. The addition of tea extract and heating temperature have significant $(\mathrm{P}<0.05)$ effect on the clarity and color while have no effect on the thickness.

Keywords: Antimicrobial edible film, tea leaves' extract (Camellia sinensis), gelatin, chicken bone

\section{PENDAHULUAN}

Gelatin merupakan suatu polipeptida larut hasil hidrolisis parsial kolagen yang merupakan konstituen utama dari kulit, tulang, dan jaringan ikat hewan. Gelatin memiliki sifat yang khas, yaitu berubah secara reversible dari bentuk sol ke bentuk gel, mengembang dalam air dingin, dapat membentuk film serta mempengaruhi viskositas suatu bahan (Junianto et.al.,2006). Sifat gelatin yang larut dalam air membuat gelatin dimanfaatkan dalam banyak industri baik industri pangan maupun non pangan untuk berbagai keperluan (Wahyuni, 2009).

Salah satunya gelatin dijadikan sebagai bahan pembuat edible film (pembungkus atau pelapis yang dapat dimakan), karena memiliki sifat berubah secara reversible dari bentuk sol ke gel atau sebaliknya. Salah satu bahan pengemas yang sering digunakan adalah plastik yang selain mengandung bahan kimia yang cukup berbahaya, penggunaannya juga telah banyak menyumbangkan limbah yang sulit diuraikan. Meningkatnya kesadaran masyarakat akan masalah kesehatan dan lingkungan memicu kenaikan permintaan kemasan biodegradable yang mampu menjamin keamanan produk pangan. Edible film merupakan suatu lapis tipis yang melapisi bahan pangan yang layak dikonsumsi, dan dapat terdegradasi oleh alam secara biologis. 
Selain bersifat biodegradable, edible film dapat dipadukan dengan komponen tertentu yang dapat menambah nilai fungsional dari kemasan itu sendiri seperti zat antioksidan dan antimikrobia.

Penambahan antimikrobia dan antioksidan pada pembuatan edible film dapat mencegah terjadinya oksidasi penyebab ketengikan. Zat antimikrobia dan antioksidan salah satunya terdapat pada tanaman teh (Camellia sinensis), kandungan kimiawi teh sama seperti yang terkandung dalam daun teh segar, yaitu senyawa polifenol (flavonol, flavanol, flavones, flavanone, isoflavone, antocyanin) (Hartoyo, 2003), teofilin, teobromin (Kardinan, 2003), vitamin C, vitamin E, Vitamin B Kompleks serta jumlah mineral seperti fluor, fosfor, kalsium, stronsium, Fe, Zn, Mg dan Mo (Fulder, 2004). Polifenol paling banyak ditemukan dalam teh adalah flavanol, yaitu katekin. Katekin dalam teh terdiri atas epigallocathechin-3-gallate (EGCG), epigallocathecin (EGC), epicathecin-3-gallate (ECG), dan epicathecin (EC) (Hartoyo, 2003).

Penambahan ekstrak daun teh (Camellia sinensis) diharapkan mampu menambah lama masa simpan dan mencegah terjadinya oksidasi pada produk pangan. Gelatin film dapat terbentuk dengan adanya $20-30 \%$ gelatin dan $10-30 \%$ plastizier (gliserine) dan $40-70 \%$ air pada saat mengeringkan gel gelatin (Bourtoom, 2008). Pembuatan antimicrobia edibel film yaitu gelatin, plastizier (gliserine), aquades ditambahkan dengan ekstrak daun teh dan diaduk larutan tersebut menggunakan magnetic stirrer pada suhu dengan dipanaskan dengan suhu tertentu selama beberapa menit, tuang larutan kedalam cetakan sehingga menjadi bentuk lembaran /film.

\section{MATERI DAN METODE}

Bahan baku penelitian yang digunakan pada pembuatan antimicrobial edible film adalah serbuk gelatin tulang ayam dan ekstrak daun teh. Bahan kimia untuk analisis kimia diantaranya adalah larutan $\mathrm{HCl} 37 \%$, plastizier (glyserin), dan CMC.

Peralatan yang digunakan pada penelitian ini antara lain peralatan laboratorium seperti Timbangan Analitik (Ohaus), Oven (Memmert), Spektrofotometer UV-VIS (Genesys 10S), Inkubator dan lain-lain. Peralatan gelas dan peralatan lain yang mendukung antara lain, erlenmeyer, tabung reaksi, gelas ukur, dan kertas saring.

Variabel yang diamati dalam penelitian ini yaitu karakteristik kualitas fisik antimicrobial edible film meliputi rendemen, warna, kejernihan, pH, viskositas, ketebalan. Berikut alat dan cara pengukuran :

Warna dan Tingkat Kejernihan (Schriber dan Gereis, 2007).

Larutan edible film baik ekstrak atau non ekstrak disiapkan dalam kaca spektrofotometer. Warna dan kejernihan AmEF diuji mengunakan alat spekrofotometer UV-Vis dengan panjang gelombang $450 \mathrm{~nm}$ untuk warna dan 620 nm untuk kejernihan (Schrieber, 2007).

Pengukuran Ketebalan (Akili dkk., 2012)

Film yang dihasilkan diukur ketebalannya dengan menggunakan mikrometer $(0,001 \mathrm{~mm})$. Pegukuran pada 4 tempat yang berbeda.

\section{HASIL}

\section{Kejernihan AmEF Gelatin Tulang Ayam}

Data rerata kejernihan AmEF dari gelatin tulang ayam dengan penambahan ekstrak daun teh $20 \%$, 25\%, 30\%, 35\%, 40\% pada suhu pemanasan $70^{\circ} \mathrm{C}$ dan $80^{\circ} \mathrm{C}$ selama penelitian disajikan pada Tabel 1. 
Tabel 1. Rerata Kejernihan (abs) AmEF Gelatin Tulang Ayam dengan Penambahan Ekstrak Teh (\%) dan Suhu Pemanasan $\left({ }^{\circ} \mathrm{C}\right)$ yang berbeda.

\begin{tabular}{|c|c|c|c|c|c|c|c|}
\hline \multirow{2}{*}{ Suhu Pemanasan } & \multicolumn{6}{|c|}{ Konsentrasi Ekstrak Teh } & \multirow{2}{*}{ Rerata } \\
\hline & 0 & 20 & 25 & 30 & 35 & 40 & \\
\hline 70 & 0,62 & 1,80 & 1,89 & 1,91 & 2,03 & 2,12 & 1,7 \\
\hline 80 & 0,85 & 1,86 & 1,81 & 1,97 & 1,90 & 1,96 & 1,7 \\
\hline Rerata & $0,74^{\mathrm{a}}$ & $1,83^{\mathrm{b}}$ & $1,85^{\mathrm{bc}}$ & $1,94^{\text {bcd }}$ & $1,96^{\mathrm{cd}}$ & $2,04^{\mathrm{d}}$ & \\
\hline
\end{tabular}

a, b, c, d : Superskrip yang berbeda menunjukan perbedaan $(\mathrm{P}<0,05)$.

Berdasarkan uji statistik pada Tabel 1, menunjukan interaksi pada perlakuan penambahan konsentrasi ekstrak teh dan suhu pemanasan berbeda nyata $(\mathrm{P}<0.05)$ terhadap kejernihan. Hal ini menunjukan bahwa perlakuan konsentrasi dan suhu pemanasan yang berbeda pada penelitian mempengaruhi kejernihan AmEF gelatin tulang ayam. Kejernihan AmEF yang dihasilkan berkisar antara 0,62-2,12 abs lebih rendah nilainya dari penelitian sebelumnya. Puspitasari dkk (2013) memiliki nilai warna larutan gelatin tulang ayam berkisar antara 2,15 - 3,04 abs.

Kejernihan AmEF tertingi didapatkan pada konsentrasi ekstrak teh $40 \%$ sebesar 2,12 abs pada suhu pemanasan $70^{\circ} \mathrm{C}$ dan 1,96 - 1,97 abs pemanasan $80^{\circ} \mathrm{C}$ pada konsentrasi ekstrak teh 30\% dan 40\%. Kejernihan AmEF terendah sebesar 1,80 abs pada konsentrasi ekstrak teh $20 \%$ dan pemanasan $70^{\circ} \mathrm{C}$ sedangkan pada pemanasan $80^{\circ} \mathrm{C}$ sebesar 1,81 abs pada konsentrasi ekstrak teh 25\%. kejernihan AmEF terbaik dihasilkan dari konsentrasi ekstrak teh
$20 \%$ pada suhu pemanasan $70^{\circ} \mathrm{C}$ sebesar 1,80 abs.

Semakin tinggi nilai tingkat kejernihan, menunjukkan tingkat kejernihan semakin rendah. Puspitasari dkk. (2013) menyatakan tingkat kejernihan berbanding terbalik dengan nilai turbidity. Semakin tinggi turbidity maka, tingkat kejernihannya akan semakin rendah. Rendanya tingkat kejernihan disebabkan oleh adanya partikel tidak larut yang menghamburkan cahaya dan adanya partikel yang menyebabkan kekeruhan pada larutan ( Cole, 2012).

Penambaan ekstrak teh merupakan salah satu penyebab kekeruhan pada larutan AmEF. Selain itu rendanya kejernihan dapat disebabkan oleh kontaminasi anorganik, dan protein dari gelatin bahan terjadi ketika proses ekstraksi pembuatan gelatin (Remawati, 2016). Idealnya kejernihan larutan AmEF gelatin tulang ayam harus sama dengan aquades (Cole, 2012).

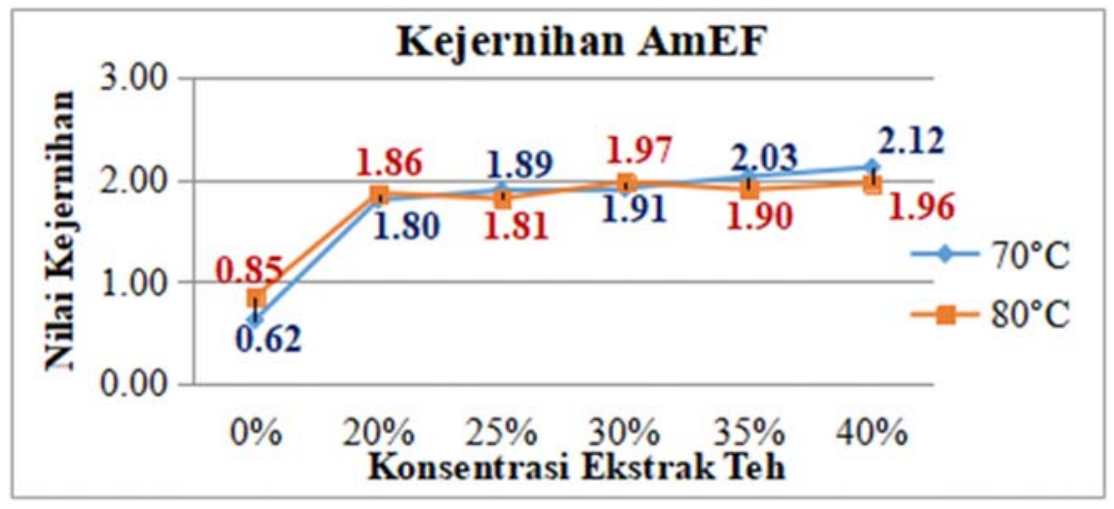

Gambar 1. Grafik Kejernihan AmEF Gelatin Tulang Ayam

Interaksi antara konsentrasi ekstrak teh dengan suhu pemanasan berbeda nyata $(\mathrm{P}<0.05)$ terhadap kejernihan AmEF gelatin tulang ayam. Pada Gambar 1. dapat disimpulkan bahwa kenaikan terjadi seiring bertambahnya konsentrasi ekstrak teh baik pada suhu pemanasan $70^{\circ} \mathrm{C}$ dan $80^{\circ}$. Nilai tertinggi berada pada konsentrasi $40 \%$ sebesar 2,12 abs dan terendah pada konsentrasi 20\% 1,80 abs pada pemanasan $70^{\circ} \mathrm{C}$. Pada pemanasan $80^{\circ} \mathrm{C}$ kenaikan terjadi pada konsentrsai 30\% dan 40\% 
sebesar 1.97 abs dan 1,96 abs dan terendah pada konsentrasi $25 \%$ sebesar 1,81 abs.

\section{Warna AmEF Gelatin Tulang Ayam}

Data rerata warna AmEF dari gelatin tulang ayam dengan penambahan ekstrak daun teh $20 \%$, 25\%, 30\%, 35\%, 40\% pada suhu pemanasan $70^{\circ} \mathrm{C}$ dan $80^{\circ} \mathrm{C}$ selama penelitian disajikan pada Tabel 2 .

Tabel 2. Rerata Warna (abs) AmEF Gelatin Tulang Ayam dengan Penambahan Ekstrak Teh (\%) dan Suhu Pemanasan $\left({ }^{\circ} \mathrm{C}\right)$ yang berbeda.

\begin{tabular}{|c|c|c|c|c|c|c|c|}
\hline \multirow{2}{*}{ Suhu Pemanasan } & \multicolumn{6}{|c|}{ Konsentrasi Ekstrak Teh } & \multirow{2}{*}{ Rerata } \\
\hline & 0 & 20 & 25 & 30 & 35 & 40 & \\
\hline 70 & 0,87 & 2,14 & 2,30 & 2,33 & 2,47 & 2,60 & 2,0 \\
\hline 80 & 1,07 & 2,23 & 2,18 & 2,40 & 2,35 & 2,47 & 2,0 \\
\hline Rerata & $0,97^{\mathrm{a}}$ & $2,19^{b}$ & $2,24^{b}$ & $2,36^{\mathrm{c}}$ & $2,41^{\mathrm{cd}}$ & $2,53^{\mathrm{d}}$ & \\
\hline
\end{tabular}

a, b, c, d : Superskrip yang berbeda menunjukan perbedaan $(\mathrm{P}<0,05)$.

Berdasarkan uji statistik pada Tabel 2, menunjukan interaksi pada perlakuan penambahan konsentrasi ekstrak teh dan suhu pemanasan berbeda nyata $(\mathrm{P}<0.05)$ terhadap warna AmEF. Hal ini menunjukan bahwa perlakuan konsentrasi dan suhu pemanasan yang berbeda pada penelitian mempengaruhi warna AmEF gelatin tulang ayam. Warna AmEF yang dihasilkan berkisar antara 0,872,60 abs, lebih rendah nilainya dari pada penelitian sebelumnya. Puspitasari dkk (2013) memiliki nilai warna larutan gelatin tulang ayam berkisar antara 2,47 - 3,30 abs.

Warna AmEF tertingi didapatkan pada konsentrasi ekstrak teh $40 \%$ sebesar 2,60 abs pada suhu pemanasan $70^{\circ} \mathrm{C}$ dan 2,47 abs pada pemanasan $80^{\circ} \mathrm{C}$. Warna AmEF terendah sebesar 2,14 abs pada konsentrasi ekstrak teh $20 \%$ dan pemanasan $70^{\circ} \mathrm{C}$ sedangkan pada pemanasan $80^{\circ} \mathrm{C}$ sebesar 2,18 abs pada konsentrasi ekstrak teh 25\%. Warna AmEF terbaik dihasilkan dari konsentrasi ekstrak teh $20 \%$ pada suhu pemanasan $70^{\circ} \mathrm{C}$ sebesar 2,14 abs. Semakin tinggi nilai warna, menunjukan warna AmEF semakin pekat yang nantinya berpengaruh pada penampilan AmEF pada produk yang dikemas (Puspitasari dkk., 2013). Karakteristik warna ekstrak teh yang pekat dan perlakuan konsentrasi ekstrak teh dan suhu pemanasan menjadi penyebab meningkatnya nilai warna pada AmEF akibat kekeruhan.

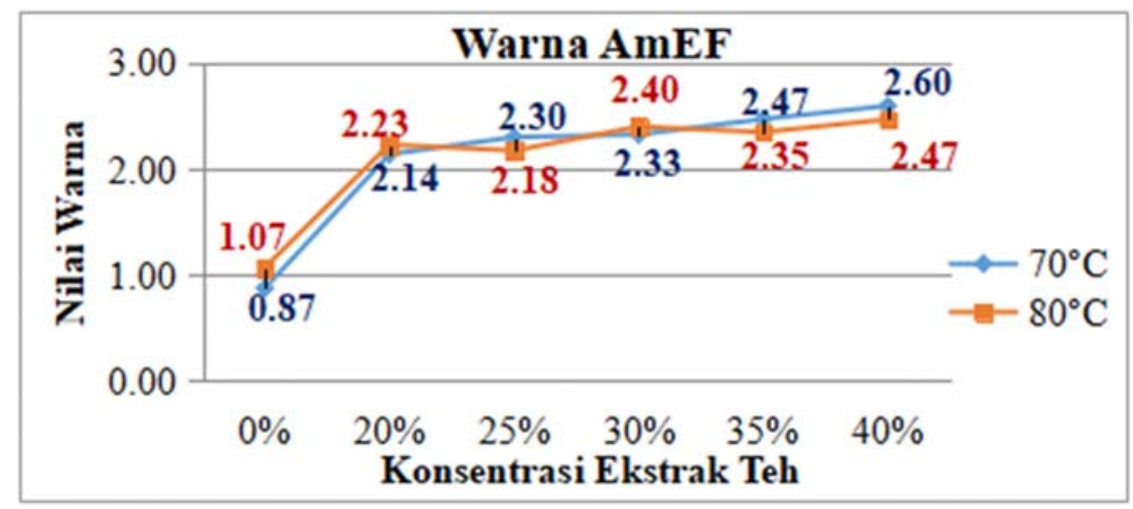

Gambar 2. Grafik Warna AmEF Gelatin Tulang Ayam

Interaksi antara konsentrasi ekstrak teh dengan suhu pemanasan berbeda nyata $(\mathrm{P}<0.05)$ terhadap warna AmEF gelatin tulang ayam. Pada Gambar 2. dapat disimpulkan bahwa kenaikan terjadi seiring bertambahnya konsentrasi ekstrak teh baik pada suhu pemanasan $70^{\circ} \mathrm{C}$ dan $80^{\circ}$. Nilai tertinggi berada pada konsentrasi $40 \%$ sebesar 2,60 abs dan terendah pada konsentrasi 20\% 2,14 abs pada pemanasan $70^{\circ} \mathrm{C}$. Pada pemanasan $80^{\circ} \mathrm{C}$ 
kenaikan terjadi pada konsentrsai $40 \%$ sebesar 2,47 abs dan terendah pada konsentrasi $25 \%$ sebesar 2,18 abs.

\section{Ketebalan AmEF Gelatin Tulang Ayam}

Data rerata ketebalan AmEF dari gelatin tulang ayam dengan penambahan ekstrak daun teh $0 \%, 20 \%, 25 \%$, 30\%, 35\%, $40 \%$ pada suhu pemanasan $70^{\circ} \mathrm{C}$ dan $80^{\circ} \mathrm{C}$ selama penelitian disajikan pada tabel 3 .

Tabel 3. Rerata Ketebalan (mm) AmEF Gelatin Tulang Ayam dengan Penambahan Ekstrak The (\%) dan Suhu Pemanasan $\left({ }^{\circ} \mathrm{C}\right)$ yang berbeda.

\begin{tabular}{|c|c|c|c|c|c|c|c|}
\hline \multirow{2}{*}{$\begin{array}{c}\text { Suhu } \\
\text { Pemanasan }\end{array}$} & \multicolumn{6}{|c|}{ Konsentrasi Ekstrak Teh } & \multirow{2}{*}{ Rerata } \\
\hline & 0 & 20 & 25 & 30 & 35 & 40 & \\
\hline 70 & 0,019 & 0,023 & 0,021 & 0,017 & 0,016 & 0,016 & 0,019 \\
\hline 80 & 0,018 & 0,015 & 0,016 & 0,018 & 0,019 & 0,020 & 0,018 \\
\hline Rerata $^{\text {ns }}$ & 0,018 & 0,019 & 0,019 & 0,017 & 0,018 & 0,018 & \\
\hline
\end{tabular}

ns: Non signifikan.

Berdasarkan uji statistik pada Tabel 3, menunjukan interaksi pada perlakuan penambahan konsentrasi ekstrak teh dan suhu pemanasan tidak berbeda nyata $(\mathrm{P}>0.05)$ terhadap ketebalan AmEF gelatin tulang ayam. Hal ini menunjukan bahwa perlakuan konsentrasi dan suhu pemanasan yang berbeda pada penelitian tidak berpengaruh nyata terhadap nilai viskositas AmEF gelatin tulang ayam. Nilai ketebalan yang dihasilkan berkisar antara 0,015 mm - 0,023 mm. Nilai ketebalan tertingi didapatkan pada konsentrasi ekstrak teh $20 \%$ sebesar $0,023 \mathrm{~mm}$ pada suhu pemanasan $70^{\circ} \mathrm{C}$ dan pada pemanasan $80^{\circ} \mathrm{C}$ pada konsentrasi ekstrak teh $40 \%$ sebesar $0,020 \mathrm{~mm}$. Skurtys, dkk. (2011) menyatakan bahwa rata- rata standar ketebalan edible film kurang dari $0,25 \mathrm{~mm}$.

Faktor yang dapat mempengaruhi ketebalan AmEF adalah sifat dan komposisi bahan. Hal ini sesuai dengan pendapat (Rachmawati, 2011) yang menyatakan bahwa faktor yang mempengaruhi ketebalan edible film adalah sifat dan komponen penyusun pembentuk edible film. Ketebalan AmEF dapat dipengaruhi oleh cetakan film yang kurang rata, sehingga terjadi penumpukan cairan AmEF yang berlebih pada beberapa sisi dan setelah pengeringan didapatkan lembaran AmEF yang memiliki ketebalan yang berbeda disetiap sisi. Menurut Park et al.(1993), ketebalan film dipengaruhi oleh luas cetakan, volume larutan, dan banyaknya total padatan dalam larutan.

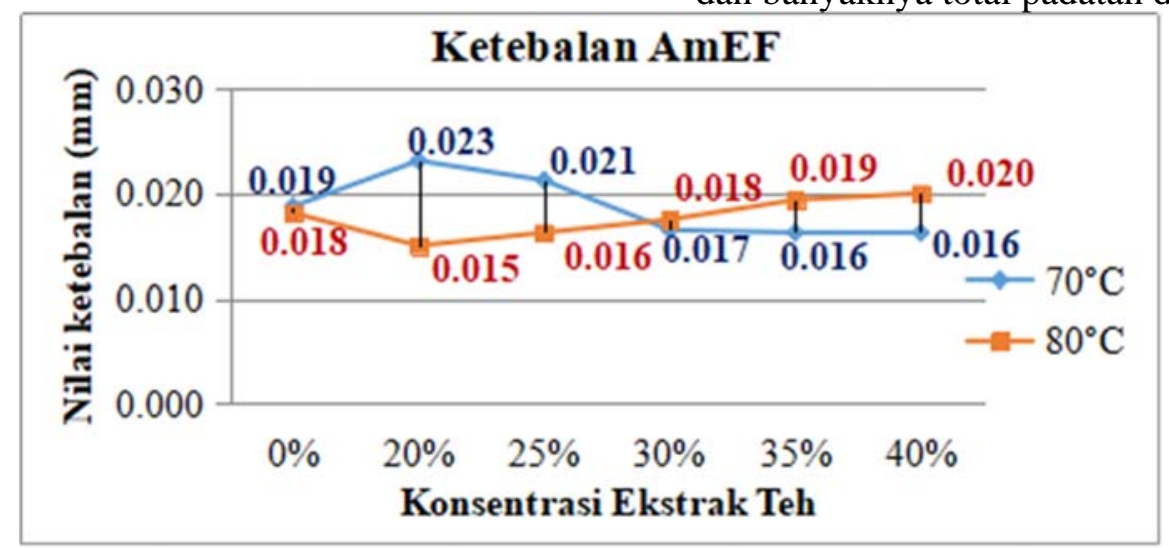

Gambar 3. Grafik Ketebalan AmEF Gelatin Tulang Ayam

Interaksi antara konsentrasi ekstrak teh dengan suhu pemanasan tidak berbeda nyata ( $\mathrm{P}>0.05)$ terhadap ketebalan AmEF gelatin tulang ayam. Pada Gambar 3. dapat disimpulkan bahwa pemanasan $70^{\circ} \mathrm{C}$ terjadi kenaikan pada konsentrasi $20 \%$ sebesar 0,023 mm dan mengalami penurunan seiring bertambahnya konsentrasi ekstrak teh. Berbeda dengan pemanasan $80^{\circ} \mathrm{C}$ justru terjadi penurunan pada konsentrasi $20 \%$ sebesar 0,015 $\mathrm{mm}$ dan menggalami kenaikan seiring bertambahnya konsentrasi ekstrak teh. 


\section{KESIMPULAN}

Hasil penelitian ini, menunjukan AmEF memiliki nilai kejernihan 0,62-2,12 abs, warna 0,87-2,60 abs, dan ketebalan 0,015-0,023 mm. Perlakuan penambahan konsentrasi ekstrak teh dan suhu pemanasan berbeda nyata $(\mathrm{P}<0.05)$ terhadap nilai kejernihan dan warna serta tidak berpengaruh nyata terhadap ketebalan.

\section{UCAPAN TERIMA KASIH}

Terimakasih atas Pendanaan Hibah Penelitian Kerjasama Atar Perguruan Tinggi dari DRPM Dikti dan kepada Ir. Ambar Pertiwiningrum, M.Si., Ph.D dan Yuny Erwanto, S.Pt.,M.P.,Ph.D sebagai Tim Peneliti Mitra kami.

\section{DAFTAR PUSTAKA}

Bourtoom, J. 2008. Edible filmsand coating : characteristics and properties. International Food Research Journal. 15 (3): 1-12.

Cole,C.G.B. and Roberts, J.J. 2012. Gelatine Colour Measurement. Meat Science. 45(1).

Fulder, S., 2004. Khasiat Teh Hijau. Penerjemah : T.R. Wilujeng. Prestasi Pustaka Publisher, Jakarta.

Hartoyo, A. 2003.Teh dan Khasiatnya bagi Kesehatan. Yogyakarta: Kanisius

Junianto, K. Haetami dan I. Maulina. 2006. Produksi Gelatin Dari Tulang Ikan dan Pemanfaatannya Sebagai Bahan Dasar Pembuatan Cangkang Kapsul. Hibah Penelitian Dirjen Dikti. Fakultas Perikanan dan Imu Kelautan, Universitas Padjajaran.

Kardinan A, Taryono. 2003. Tanaman Obat Penggempur Kanker. Jakarta: Agromedia Pustaka. 2003: 29-31.
Park JW, Testin RF, Vergano DJ, Park HJ, Waller CL., 1993. Application of laminated edible film to potato chip packaging. J Food Sci 61(4): 766.

Puspitasari, D. A. P., V. P. Bintoro, B. E. Setiani. 2013. Kualitas Warna, Tingkat Kejernihan Dan Tingkat Ketebalan Film Gelatin Tulang Cakar Ayam Sebagai Alternatif Bahan Dasar Edible Film. Jurnal Aplikasi Teknologi Pangan. 2(3) : 144 147.

Rahmawati, W., Y.A. Kusumastuti, and N. Aryanti. 2011. Karakterisasi pati talas (Colocasia esculenta (L.) schott) sebagai alternatif sumber pati industri di Indonesia. J. Teknologi Kimia dan Industri. Vol.1(1): 347-351.

Remawati. 2016. Ekstraksi dan Karakteristik Gelatin dari Kulit Sapi Menggunakan Metode Hidrolisis Asam. Skripsi. Fakultas Kedokteran dan Ilmu Kesehatan Program Studi Farmasi UIN Syarif Hidayatullah, Jakarta.

Schrieber, R. and H. Gareis. 2007. Gelatine Handbook Theory and Industrial Practice. WILEY-VCH Verlag GmbH \& Co KgaA.

Skurtys, B., N. Gonthard, J. L. Cuq, and S. Guilbert. 2011. Functional Properties of Myofibrillar Protein-Based Biopacking as Affected by Film Thickenes. Journal of Food Science.61(3).

Wahyuni, Mita dan Peranginangin, Rosmawat. 2009. Perbaikan Daya Saing Industri Pengolahan Perikanan Melalui Pemanfaatan Limbah Non Ekonomis Ikan Menjadi Gelatin, (www.ikanmania.wordpress.com). 